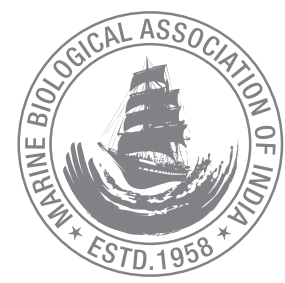

\title{
Efficacy of spatial study on catch and effort from fishing vessels for strengthening fisheries management
}

\author{
A. P. Dineshbabu*, Sujitha Thomas and S. Shailaja \\ ICAR- Central Marine Fisheries Research Institute, Mangalore - 57 5001, Karnataka, India. \\ *Correspondence e-mail: dineshbabuap@yahoo.co.in
}

Received: 30 Nov 2016, Accepted: 30 Jun 2017, Published: 10 July 2017

Original Article

\begin{abstract}
Ever since marine fishery operations were extended beyond territorial waters of respective states, the need was felt for incorporating spatial component of fishing effort and catch for formulating marine fishery policies. The present study is an attempt of spatio-temporal analysis of changing scenario of fishing operations in GIS platform with catch and effort data collected from fishermen, to highlight the need for the change in approach in fisheries management and also for updating the information of fishing along the Indian coast. Marine fishing operations by commercial fishing vessels operated from different states has extended up to $200 \mathrm{~m}$ depth since 2000 and duration of fishing, especially trawling extended from single day to 8-13 days per voyage. Present findings were drawn from the analysis of 1,217 days of trawling operations during 2007-2013 by a sampling trawler supplemented by additional fishing operational data support from a group of commercial trawlers. Study reveals that there is an organised and confidential maintenance of log sheets in most of the progressive trawler operators and the information available in spatial platform can be utilized for better fisheries management with fishermen's participation. Spatial analysis of fish catch from the sampling trawler operated from Mangalore showed that more than $70 \%$ of the fish landed in Mangalore was brought from the area beyond the territorial waters of Karnataka signifying that majority of fish catch landing to the state is from waters beyond their jurisdiction. Even though the fishery beyond territorial waters of all
\end{abstract}

maritime states is governed by Government of India, so far, there is no comprehensive management plans regarding fishing operations beyond territorial waters of the states. The study further reveals that fishing grounds beyond territorial waters of each state are being intensively fished without any fishing regulations and there were many conflicts being reported from these waters concerning the fishing rights of different sectors and different states. In the light of the findings from the study on fishing operations and fishery, an action plan to regulate the fishery off the territorial waters of each state is felt essential. "Regional fisheries committees" with members constituting the officials from neighbouring states sharing same resources with the aegis of Central Government is recommended as a viable option to take care of the management of the fishery within the Indian EEZ.

Keywords: Marine fishery policy, territorial waters, fishing pressure, fisheries governance, GIS platform.

\section{Introduction}

Globally, marine fisheries has been highly dynamic in nature with updated technologies over the period of time. In India, by 
early eighties onwards mechanised vessels especially trawlers started contributing major part of the total marine fish production (Srinath et al., 2003). Trawlers from most of the maritime states are involved in multi-day trawling practices extending from 9 to 13 days across the territorial boundaries of neighboring states (Dineshbabu et al., 2013). In India, from legislative point of view, "fisheries" is a "subject" under state list as per article 21 of the Indian Constitution, and management and control of coastal fisheries is vested with the maritime states and union territories. Comprehensive Marine Fishing Policy of Ministry of Agriculture, Government of India released in 2004 (DAHD, 2004) reviewed the present status of fishery regulation in coastal waters. It recognises that, though the Marine Fisheries Regulation Acts (MFRAs) of coastal states and Union Territories have adequate provisions for management of resources and fishing operations, it is often found falling short of effective implementation. It also raised concern that "exploitation of living resources within 50 metres depth zone is showing symptoms of depletion and in certain belts in the inshore waters it tends to cross optimum sustainable levels". One of the most promising suggestions in the policy is to introduce the marine spatial planning and ecosystem based fisheries management (DAHD, 2004). Present study investigates, the possibility of introduction of marine spatial planning in Indian marine fisheries, with the help of the data available with fishermen for the effective management of marine ecosystem and also to reduce the conflicts in sea.

In recent years, incidents of conflicts among different stakeholders of the fisheries sector is on the increase, which arise mostly due to the disparities in sharing the limited resources (Vivekanandan et al., 2010). Policy demands demarcation of area for traditional, motorised and small-mechanised fishing vessels and efforts would be made to harmonize the demarcation of reserved areas to the maximum extent possible. Similar demarcation is being carried out in many countries to reduce inter-sectoral conflicts (Caddy and Carocci, 1999). Considering the country's diverse and vast coastline, multi-species multi-gear scenario, it was felt that regional specific management plans are most suitable for Indian peninsula (Vivekanandan et al., 2003). Internationally marine spatial planning (MSP) and ocean zoning has become a crucial step in supporting ecosystem based marine fisheries management (Douvere, 2008). GIS based spatial studies were projected as a management tool in marine fisheries policy development (Maeden, 2013) and stressed upon such studies in those countries, where the data available from the traditional data collection system is inadequate in reaching a sensible compromises between, fishers, scientists and politicians. In the Indian scenario the major problem in spatial planning of fishing is non-availability of spatial data on fishing effort and catch. St. Martin and Hall-Arber (2008) demonstrated the utility of participatory method of data sharing between fishermen and researchers in resource mapping to understand the fishing complexities in multi-species multi-gear scenario. Spatial data analysis is being considered as a basic requirement to formulate policies in fisheries resource conservation and fishing pressure estimation in coastal waters and governmental agencies are encouraging this concept with number of projects (Black et al., 2013; Baird et al., 2011; Baird et al., 2015). In India also the protocols are developed in spatial analysis of fishing effort data (Dineshbabu et al., 2016) and attempt for resource mapping by participatory approach along Karnataka coast was done by Dineshbabu et al. (2012). Present study focuses on an important issue flagged in the Comprehensive Marine Fisheries Policy (DAHD, 2004) in terms of fishery governance and fishing pressure. It is an attempt to analyse the changing scenario of fishing operations in space and time, with analysis of catch and effort data from the trawlers in GIS platform and the study also demonstrate the possibilities of incorporating the fishermen data in marine fisheries management and to solve some of the socio-political issues.

\section{Material and methods}

Spatio-temporal data on catch and effort collected from 1,217 days of trawl operations for six continuous fishing years (20072013) formed the data base for the present study. Crew of sampling trawler identified were given training in spatial data collection and were provided with specially designed logbooks. There was no pre-planned cruise schedule and the fishing boats are allowed to follow their traditional trawling track throughout the period of study along with other commercial trawlers (Graham et al., 2002). This was done to make the data as unbiased as possible and also to follow their traditional knowledge of selection of fishing ground by the fishers (Wiber et al., 2004). On board information collected followed the methodology developed for the spatio temporal data collection and resource mapping in India (Dineshbabu et al., 2016) Geomedia software was used for the mapping of fishing effort and fish catch from different geographical area of fishing with the methodology described by Wood and Baird (2010). Apart from the exhaustive data on fishing, data on fishery, fish biology and fishing operational details were recorded in log book from four commercial trawlers operated during the same period. Additional data points recorded in the log sheet of four commercial trawlers were used as a supplementary data, to fill up the fishing points not recorded in the sampling boat data. However in overall analysis, the pattern of fishing was found to be similar in all trawlers. The period of fishing was classified into fishing years, which generally commenced from August to June next year. Continuous data for six years, except for the period of mechanised fishing ban period were analysed in the study. The mapping of catch and effort for 1,217 days of trawl operations in 135 fishing cruises were carried out with mapping of catch and effort with reference to depth contours of $20 \mathrm{~m}, 30 \mathrm{~m}, 50 \mathrm{~m}, 100 \mathrm{~m}$ and beyond. Attempts were made 
in identifying the depth zones of high intensity fishing pressure in the light of concerns in the Comprehensive Marine Fishery Policy document (DAHD, 2004) regarding over-exploitation of resources within $50 \mathrm{~m}$ depth zone.

\section{Results}

\section{Area of operation}

During the period 2007-2013, multiday trawlers from Mangalore were operated from Ratnagiri coast of Maharashtra in north and Calicut coast of Kerala in the south with depth of operation extending from 150 to $200 \mathrm{~m}$. It was understood that a systematic pattern of fishing operation was followed from the trawlers operated from Mangalore with a season specific path and depth of operation. From the fishing operational data available from sampling boat and the commercial boats it was found that immediately after "monsoon trawl ban", the trawlers from Mangalore concentrated in fishing beyond $50 \mathrm{~m}$ depth. It was reported that during this period the trawling grounds within $50 \mathrm{~m}$ depth have very low in fish assemblage due to monsoon related bottom disturbance. In August and September, the fishers generally target thread fin breams, groupers and cephalopods. Good catch of ribbonfishes were observed in the catch during this period in some years. Off late, pufferfish and Lagocephalus also formed a good portion of the catch, which is also becoming a targeted fishery since it found commercial market in Mangalore Fisheries harbour from 2010. It was observed that invariably in all the years, by the end of October, fishing operation shifted to the fishing ground within $50 \mathrm{~m}$ depth zone and till the end of the fishing seasons trawlers invariably conduct trawling operation within $50 \mathrm{~m}$ depth zone. Low operational cost and good market demand for juveniles from fish meal plants are said to be a major reasons for intensive combing of trawlers in the lower depth zone.

\section{Distribution of fishing effort in different depths}

Spatial analysis of 1,217 days of fishing operations were carried out to understand the areas of high fishing pressure during long time series study (six years). Of 1,217 days of trawl fishing (average 240 days per year), 1,045 days of fishing was carried out within $100 \mathrm{~m}$ depth zone of which 730 days of trawling (60\% of the total fishing days) were within $50 \mathrm{~m}$ depth zone (Fig.1). The additional data collected from the commercial trawler operators also showed the similar trend. Highest percentage of fishing operation was found to be within and around $50 \mathrm{~m}$ depth zone. A regular trawling pattern observed in all the trawler studied was that, even though fishing depth was extended up to $200 \mathrm{~m}$, the fishing operation beyond $50 \mathrm{~m}$ depth zone was occurring mainly during, August-September and March-April. From October onwards the trawlers concentrate within $100 \mathrm{~m}$ depth zone. While calculating the fishing pressure or distribution of fishing operation, with reference to the territorial waters of

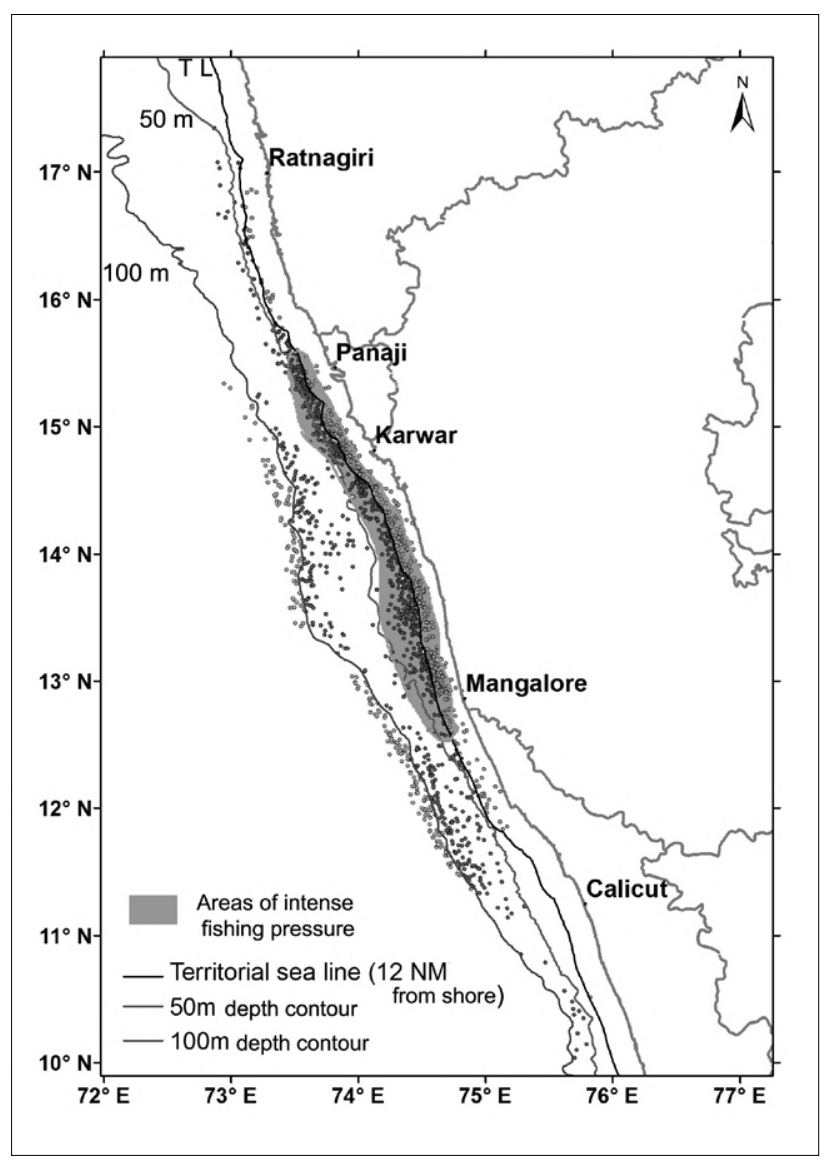

Fig.1. Distribution of fishing effort mapped off Karnataka during 20072013

Karnataka, it was found that only $28 \%$ of the cruises are falling within the territorial waters of 12 nautical miles and $72 \%$ of the operations are beyond territorial waters of Karnataka. It is to be mentioned that average depth range of territorial waters of Mangalore falls within $30 \mathrm{~m}$ depth.

\section{Spatial distribution of fish catch in relation to territorial waters}

To understand the contribution of fishes brought by trawlers, operating from Mangalore fisheries harbour, the fishes caught by the sampling trawler were subjected to spatial analysis. The catches brought from territorial waters and beyond territorial waters of Karnataka were analysed separately (Fig. 2). It was found that $70 \%$ of the catch by trawlers operating from Mangalore was brought from the waters beyond 12 nautical miles (Table 1). The analysis was carried out to point out that the fishery management from each state should take care of the resources beyond their territorial waters, since most of their fishery income is coming from the water beyond their fishery jurisdiction and to sustain the state fishery production, care should be taken to manage the fishery beyond their territorial waters too. 


\section{Discussion}

The result from the long term spatial analysis of catch and effort from the trawlers operated from Mangalore brings out very important points which need the attention in future marine fishery policy development. Ever since the advancement of mechanisation adopted in the fishery sector, the fishery extended beyond territorial waters (Dineshbabu et al., 2013). This extension of fishing ground demands inclusion of spatial dimension in the fishery data analysis to come out with present sea truth information. Since India is not having a compulsory log book keeping system, spatial studies of marine fisheries

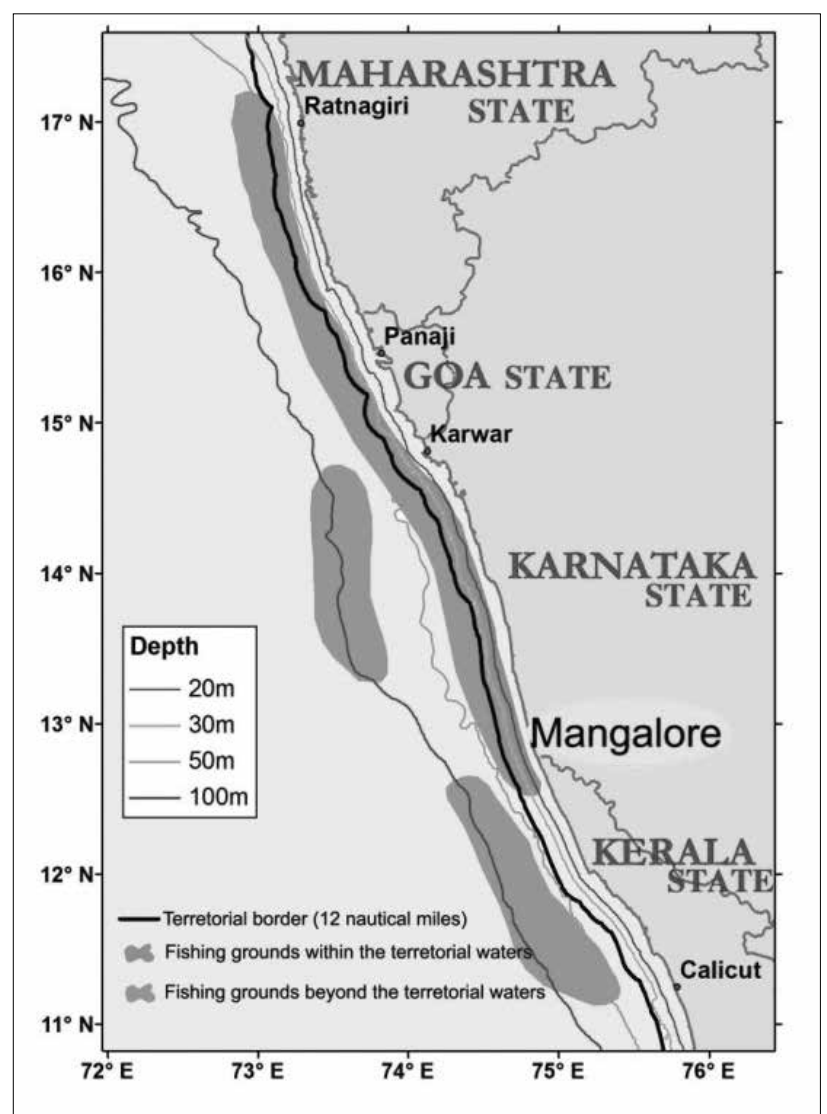

Fig.2. Mapping of fishing grounds and catch to find out the contribution of fish catch from territorial waters and beyond has been a difficult task, but study showed that there is an organised log data maintenance in most of the progressive trawler operators, which are being used as the record of area of high catch and low catch with species information. These data base is generally kept confidential with limited access to group members. Such an organised log sheet maintenance opens up very promising future for involvement of fishermen in deriving fishery management policies. Involvement of local fishermen in spatial data collection process for GIS analysis are proved to be a very handy and useful input for developing management tools (Hutching and Ferguson, 2000; Maurstad, 2000). The team lead by Graham et al. (2002) could succeed in preparing "Atlas on ground fish spawning in Bay of Fundy" with participatory research program involving commercial fishermen and similar methodology is adopted in the present study also. Resource mapping along Karnataka coast with fishermen's participation was done by Dineshbabu et al. (2012). Present study revealed that the marine fishing scenario have undergone significant changes in terms of operational depth and area. These changes should be reflected in future fishery management plans for better regulation of the fishery and for sustaining many of the fishery resources. It was understood that trawl fishing is being carried out in very organised manner with most of the trawler operating groups keeping very elaborative log sheet, which is kept in high confidentiality, which is shared only with their own group members. Prevalence of this practices, can be considered as promising opportunity for bringing in spatiotemporal suggestions to sustain the production.

The issue of cross border fishing is raised as a serious concern in the comprehensive Marine fishery policy (DAHD, 2004). Since the space sharing and resource sharing among different states is a reality, there is a need for more spatial analysis of catch and effort data from different states, to reduce the conflicts in the sea. Since fishery beyond territorial waters is governed by Government of India, "regional fisheries committees" with members constituting the officials from neighbouring states sharing same resources with the support of Central Government is a necessity. Even with analysis of trawl fishery alone, present study also endorses the concern raised in the Comprehensive Marine fishery policy document that highest fishing pressure is within $50 \mathrm{~m}$ depth

Table 1. Spatial analysis of catch from sampling trawlers operated from Mangalore

\begin{tabular}{|c|c|c|c|c|c|c|c|}
\hline Year & Number of operations & Number of days & Catch $(\mathrm{kg})$ & within $12 \mathrm{NM}$ & percentage & Outside $12 \mathrm{NM}$ & Percentage \\
\hline 2007-2008 & 20 & 175 & 124968 & 45238 & 36.2 & 79730 & 63.8 \\
\hline 2008-2009 & 23 & 221 & 185692 & 62021 & 33.4 & 123671 & 66.6 \\
\hline $2009-2010$ & 22 & 195 & 187164 & 57646 & 30.8 & 129517 & 69.2 \\
\hline $2010-2011$ & 22 & 203 & 227451 & 60047 & 26.4 & 167404 & 73.6 \\
\hline 2011-2012 & 23 & 204 & 219707 & 61957 & 28.2 & 157750 & 71.8 \\
\hline $2012-2013$ & 25 & 219 & 263010 & 66805 & 25.4 & 196205 & 74.6 \\
\hline Total & & 1217 & 1207991 & 353715 & 29.3 & 854276 & 70.72 \\
\hline
\end{tabular}


zone. The concern shown in policy document (2004) is highly relevant when the study include more craft groups like traditional crafts, motorised crafts and other mechanised crafts. The finding also give the policy makers an opportunity for re-thinking on the options and claims made by different states that, the introduction of trawlers with capability of fishing in deeper waters can reduce the fishing pressure in the nearby fishing grounds. Spatial reallocation of fishing pressure can be a method for attaining sustainability and also for avoiding conflicts in the sea (Douvere, 2008). Involving fishermen in the Marine spatial planning proved to be very efficient method in decision making on fishing area sharing and resource sharing in multi -species, multi-gear scenarios (St. Martin and Hall Arber, 2008). Similar marine spatial planning involving the contributions of all stake holders in marine fishing may be a very good option in Indian fisheries policy development, which can reduce the conflicts in the sea and can also ensure sustainability of marine fisheries resources.

\section{Acknowledgements}

The authors are thankful to Dr. A Gopalakrishnan, Director, Central Marine Fisheries Research Institute (CMFRI), Kochi for the facilities provided for the work and Dr. G. Maheswarudu, Head Crustacean fisheries Division, CMFRI, Kochi for his constant encouragement. I wish to thank Dr. Tom Nishida, of International Fishery GIS Society, Japan, for the encouragement and for mailing large number of relevant literature from Fishery GIS. The co-operation and help provided by the fishing community of Mangalore especially the owner and crew memebers of trawler group "Harikripa" and fishing operation data provided by "Sri Vinayaka" group of boat operators from Mangalore fisheries harbour are acknowledged with gratitude.

\section{References}

Baird, S. J., J. E. Hewitt and B. A. Wood. 2015. Benthic habitat classes and trawl fishing disturbance in New Zealand waters shallower than $250 \mathrm{~m}$. New Zealand Aquatic Environment and Biodiversity Report No. 144. p184 ( http://www.mpi.govt.nz/ news-resources/publications.aspx)

Baird, S. J., B. A. Wood and N. W. Bagley. 2011. Nature and extent of commercial fishing effort on or near the seafloor within the New Zealand $200 \mathrm{n}$. mile Exclusive Economic Zone, 1989-90 to 2004-05. New Zealand Aquatic Environment and Biodiversity Report No. 73.144 pp.
Black, J., R. Wood, T. Berthelsen and R. Tilney. 2013. Monitoring New Zealand's trawl footprint for deepwater fisheries: 1989-1990 to 2009-2010. New Zealand Aquatic Environment and Biodiversity Report, No. 110. p57 (http://www.mpi. govt.nz/news-resources/publications.aspx)

Caddy, J. F. and F. Carocci. 1999. The Spatial Allocation of Fishing Intensity by Portbased Inshore Fleets: A GIS Application. ICES J. Mar. Sci., 56(3): 388-403.

DAHD, 2004. Comprehensive Marine Fishing Policy. Planning Commission, Government of India, Delhi.

Dineshbabu, A. P., E. V. Radhakrishnan, Sujitha Thomas, G. Maheswarudu, P. P Manojkumar, J. K. Shoba., S. Lakshmi Pillai, C. Rekhadevi, J. Josileen, P. T. Sarada, B. S. Paramita, K. K. Philipose, V. D. Deshmukh, J. Jayasankar, S. Ghosh, M. Koya, G. B. Purushottama and G. Dash. 2013. An appraisal of trawl fisheries of India with special reference on the changing trends in bycatch utilization. J. Mar. Biol. Ass. India, 55(2): 69-78.

Dineshbabu, A. P. and Sujitha Thomas, E. V. Radhakrishnan and A. C. Dinesh. 2012. Preliminary experiments on application of participatory GIS in trawl fisheries of Karnataka and its prospects in marine fisheries resource conservation and management. Indian J. Fish, 59(1): 15-22.

Dineshbabu, A. P., Sujitha Thomas and A. C. Dinesh. 2016. Handbook on Application of GIS as a Decision Support Tool in Marine Fisheries, CMFRI Spl. Publn. No. 121. ICAR-Central Marine Fisheries Research Institute, Kochi.

Douvere, F. 2008. The importance of marine spatial planning in advancing ecosystembased sea use management The Role of Marine Spatial Planning in Implementing Ecosystem-based, Sea Use Management, Mar. Policy, 32(5): 759-761.

Graham, J., S. Engle and M. Recchia. 2002. Local Knowledge and Local Stocks: An Atlas of Ground fish Spawning in the Bay of Fundy. Antigonish, Nova Scotia: The Centre for Community-based Management, Extension Department, St. Francis Xavier University. 1-10 pp.

Hutchings, J. A. and M. Ferguson. 2000. Links between fishers' knowledge, fisheries science, and management: Newfoundland's inshore fishery for northern Atlantic cod, Gadus Morhua. In: B. Neis and L. Felt (Eds), Finding Our Sea Legs: Linking Fishery People and their Knowledge with Science and Management, ISER Books, St. John's, NF, 82-110 pp

Maeden, 2013. Fisheries GIS: is this world's most important applications-software area? GIS/Spatial analysis in fishery and Aquatic Sciences, 4: 019-034.

Maurstad, Anita. 2000. Trapped in biology: An Interdisciplinary Attempt to Integrate Fish Harvesters' Knowledge into Norwegian Fisheries Management. In Finding Our Sea Legs: Linking Fishery People and Their Knowledge with Science and Management, edited by Barbara Neis and Lawrence Felt. St. John's Newfoundland: ISER Press. 135-152 p.

Srinath, M., V. N. Pillai, E. Vivekanandan and K. N. Kurup. 2003. Demersal Fish Assemblages of the Southwest Coast of India. Assessment, Management and Future Directions for Coastal Fisheries in Asian Countries (1705). 163-186 pp.

St. Martin, K. and M. Hall-Arber. 2008. The missing layer: Geo-technologies, communities, and implications for marine spatial planning, The Role of Marine Spatial Planning in Implementing Ecosystem-based, Sea Use Management, Mar. Policy, 32(5):779-786.

Vivekanandan, E., R. Narayanakumar, T. M. Najmudeen, J. Jayasankar and C. Ramachandran. 2010. Marine Fisheries Policy Brief-2; Seasonal Fishing Ban. CMFRI Spl. Publn., 103. p. 1-44.

Vivekanandan, E., M. Srinath, V. N. Pillai, S. Immanuel and K. N. Kurup. 2003. Marine Fisheries along the Southwest Coast of India. Assessment, Management and Future Directions for Coastal Fisheries in Asian Countries (1705). 757-792 p.

Wiber, M., F. Berkes, A. Charles and J. Kearney. 2004. Participatory research supporting community-based fishery management, Mar. Policy, 28: 459-468.

Wood, B. and S. J. Baird. 2010. Mapping Bottom trawl fishing activity in the New Zealand EEZ. GIS/Spatial analysis in fishery and Aquatic Sciences (vol 4), 2013: 433-442. 